\title{
Ligand specificity of uterine oestrogen and progesterone receptors in the subadult African elephant, Loxodonta africana
}

\author{
M. D. Greyling ${ }^{1}$, R. J. van Aarde $^{1^{*}}$ and H. C. Potgieter ${ }^{2}$ \\ ${ }^{\mathrm{I}}$ Mammal Research Institute and ${ }^{2}$ Department of Chemical Pathology, University of Pretoria, \\ Pretoria 0002, South Africa
}

\begin{abstract}
The ligand specificity of progesterone and oestrogen receptors in the uteri of four nonpregnant, nonlactating African elephants, killed during routine culling in the Kruger National Park, were determined. The mean ( \pm SEM) $K_{d}$ values of the oestrogen $\left(0.18 \pm 0.019 \times 10^{-9} \mathrm{~mol} \mathrm{l}^{-1}, n=12\right)$ and progesterone $\left(0.22 \pm 0.025 \times 10^{-9} \mathrm{~mol} \mathrm{l}^{-1}\right.$, $n=12$ ) receptors were essentially similar when $\left[{ }^{3} \mathrm{H}\right]$ promegestone was used as radioligand in the progesterone receptor assays. However, when $\left[{ }^{3} \mathrm{H}\right]$ progesterone was used as radioligand, the progesterone receptor exhibited a significantly higher $K_{d}$ value ( $1.03 \pm 0.132 \times 10^{-9} \mathrm{~mol} \mathrm{l}^{-1}, n=12$ ) than that of the oestrogen receptor. The use of the different radioligands did not significantly affect the quantitative values obtained for the progesterone receptor. Both the oestrogen and the progesterone receptors displayed a high ligand specificity. The $5 \boldsymbol{\alpha}$-reduced metabolites of progesterone exhibited a high relative binding affinity for the progesterone receptor (5 $\alpha$-pregnane-3,20-dione: relative binding affinity $=43 \%$; $5 \alpha$-pregnane- $3 \alpha$-ol-20-one: relative binding affinity $=20 \%$ ) but the synthetic antiprogestin RU 486 did not compete successfully with progesterone in competitive binding studies. However, norethindrone (relative binding affinity $=293 \%$ ) competed successfully for binding to the progesterone receptor, and may have some potential in the future development of a technique to control reproductive output in the African elephant.
\end{abstract}

\section{Introduction}

Relative high annual rates of population growth in African elephants confined to conservation areas in southern Africa (for example, 7\%; Hall-Martin, 1992) may have negative consequences for the maintenance of biological diversity. As a result the densities of some of these populations are reduced artificially through culling operations that are opposed both by some conservationists and the concerned public. There is, therefore, a need for the development of alternative and generally acceptable techniques for inhibiting population growth. In this regard Poole (1993) and Short (1992) suggested that consideration should be given to the use of contraceptives or contragestins, such as an antiprogestin, like mifepristone (RU 486; Roussel Uclaf, Paris), that may block uterine receptor activity. However, the use of such treatments require detailed knowledge of the reproductive endocrinology in the elephant.

To the best of our knowledge, information on the potential of antiprogestins to interfere with uterine receptor activity in the African elephant has not been published. Previous studies have documented concentrations of progesterone and oestrogen in the plasma and the corpora lutea of the African elephant (for example, Hanks and Short, 1972; Smith and Buss, 1975; Hodges et al., 1983; McNeilly et al., 1983; Brannian et al., 1988; Plotka et al., 1988; De Villiers et al., 1989; Hodges et al., 1994).

${ }^{*}$ Correspondence

Received 4 June 1996.
Heistermann et al. (1994) documented that plasma concentrations of $5 \alpha$-dihydroprogesterone in pregnant elephants are an order of magnitude higher than those of progesterone. They also suggested that plasma concentrations of $5 \alpha$-dihydroprogesterone are more closely related to the function of the corpus luteum and reproductive status of African elephants than are plasma concentrations of progesterone. In this regard Hodges et al. (1994) illustrated that the $5 \alpha$-reduced progesterone metabolites, $5 \alpha$-pregnane-3 $\alpha$-ol-20one and $5 \alpha$-pregnane-3,20-dione ( $5 \alpha$-dihydroprogesterone) are the principal progestins, other than progesterone, produced by the elephant corpus luteum. However, information on the biological activity of the metabolites and on the potential for antiprogestins to interfere with uterine receptor activity in the elephant has not been published. The present paper thus focuses on the relative binding affinities of uterine progesterone and oestrogen receptors of the elephant for a variety of hormones and their analogues. This study was carried out on material collected from freshly killed subadult cows during routine culling for population management in the Kruger National Park of South Africa.

\section{Materials and Methods}

The radioligands $\left[1,2,6,7_{-}^{3} \mathrm{H}\right]$ progesterone $\left({ }^{3} \mathrm{H}-\mathrm{P} ; \quad\right.$ specific activity: $\left.95 \mathrm{Ci} \mathrm{mmol}^{-1}\right)\left[2,4,6,7,16,17{ }^{3} \mathrm{H}\right]$ oestradiol- $17\left(^{3} \mathrm{H}-\mathrm{E}_{2}\right.$; specific activity: $157 \mathrm{Ci} \mathrm{mmol}{ }^{-1}$ ) were obtained from 
Amersham International (Amersham, Bucks); [17(-methyl${ }^{3} \mathrm{H}$ lpromegestone $\quad\left({ }^{3} \mathrm{H}-\mathrm{R} 5020 ; \quad\right.$ specific activity: $86.7 \mathrm{Ci}$ $\mathrm{mmol}^{-1}$ ) and an unlabelled promegestone were obtained from New England Nuclear (Massachusetts, MA). All other unlabelled steroids, leupeptin and gelatine (Carraggenan Type 1) were purchased from Sigma (St Louis, MO), while SA-Druggists (Port Elizabeth) kindly donated levonorgestrel, ethinyl oestradiol, tamoxifen and danazol. Roussel Uclaf (Paris) kindly supplied RU 486. Activated charcoal was purchased from Merck Chemicals and dextran T 70 from Pharmacia Fine Chemicals.

\section{Animals and tissue collection}

Uterine tissue (four or more $1 \mathrm{~cm}^{3}$ blocks of endometrium and myometrium from each animal) was collected from four 8-10-year-old, nonpregnant, nonlactating female African elephants killed during May 1995. Samples collected from the fundus region and the corpus regions of the uterine horn were kept separately. The tissues were placed onto crushed dry ice within $30 \mathrm{~min}$ after death. They were wrapped in aluminium foil and immediately snap frozen in liquid nitrogen. Subsequently the samples were transported to the laboratory on dry ice and stored at $-70^{\circ} \mathrm{C}$ until processed. During all dissections, the endometrium was removed first as this tissue was considered to be the most important to this study.

\section{Equilibrium binding assays}

Cytosol fractions of the endometrium and myometrium were prepared separately as described by Potgieter et al. (1985). The uterine tissue was first cut into thin slices on powdered dry ice. Leupeptin (to a final concentration of $10 \times 10^{-3} \mathrm{~mol} \mathrm{l}^{-1}$ ) was added to $10 \%(\mathrm{w} / \mathrm{v})$ tissue in $\mathrm{TEDAG}_{10}$ buffer, before homogenization, to inhibit protease activity (Leake and Habib, 1987). The tissue was homogenized in three bursts of $10 \mathrm{~s}$ duration, alternated with a $50 \mathrm{~s}$ cooling period on crushed ice. A TP Ultra Turrax (Janke and Kunkel, Staufen, Germany) was used during homogenization. The homogenate was centrifuged at $105000 \mathrm{~g}$ for $30 \mathrm{~min}$ at $4^{\circ} \mathrm{C}$. The protein concentration in the cytosol was determined by the method of Bradford (1976).

Duplicate aliquots $(100 \mu \mathrm{l})$ of cytosol were incubated with either $50 \mu \mathrm{l}\left[{ }^{3} \mathrm{H}\right]$ oestradiol for the oestrogen receptor or $\left[{ }^{3} \mathrm{H}\right]$ progesterone or $\left[{ }^{3} \mathrm{H}\right]$ promegestone for the progesterone receptor. The radiolabelled compounds were made up in buffer at seven different concentrations, that ranged from $I$ to $12 \times 10^{-9} \mathrm{~mol} \mathrm{l}^{-1}$. The selection of this range was based on an initial 15-point saturation curve $\left(0.5\right.$ to $\left.64 \times 10^{-9} \mathrm{moll}^{-1}\right)$ that indicated that saturation occurred at approximately $16 \times 10^{-9} \mathrm{~mol} \mathrm{l}^{-1}$. The buffer $\left(\mathrm{TEDAG}_{10}\right)$ contained $10 \times 10^{-3} \mathrm{~mol}$ Tris-HCl $1^{-1}, 1.5 \times 10^{-3} \mathrm{~mol}^{-1}$ EDTA $1^{-1}$, $1 \times 10^{-3} \mathrm{~mol}$ dithiothreitol $1^{-1}, 1 \times 10^{-3} \mathrm{~mol}$ sodium azide $1^{-1}$ and $10 \%(\mathrm{w} / \mathrm{v})$ glycerol with the $\mathrm{pH}$ adjusted to 7.4 at $4^{\circ} \mathrm{C}$. Nonspecific binding was determined by adding 1000 -fold excess of unlabelled diethylstilboestrol (DES), or progesterone or promegestone for the oestrogen and progesterone receptor assays, respectively. All volumes in the tubes were adjusted to a final concentration of $400 \mu \mathrm{l}$ by the addition of an appropriate volume of buffer. Total count tubes contained $50 \mu$ l of the radioligand and $350 \mu \mathrm{l}$ buffer. Incubations for the oestrogen receptor lasted $30 \mathrm{~min}$ at $20^{\circ} \mathrm{C}$. Progesterone receptor assays were incubated on crushed ice for $2 \mathrm{~h}$, after which $100 \mu \mathrm{l}$ TEDAG $_{60}(60 \%$ glycerol $(w / v)$ was added, followed by an additional incubation on crushed ice for a further $2 \mathrm{~h}$. All reactions were terminated with the addition of $500 \mu \mathrm{l}$ dextrancoated charcoal. Fresh dextran-coated charcoal solutions were prepared every 2 weeks and consisted of $0.5 \%(\mathrm{w} / \mathrm{v})$ prewashed, activated charcoal, $0.1 \%(\mathrm{w} / \mathrm{v})$ gelatine and $0.5 \%$ dextran T70 in TEDAG 10 buffer. After the addition of dextrancoated charcoal, the suspension was vortexed, left on ice for $10 \mathrm{~min}$ and centrifuged at $2000 \mathrm{~g}$ for $15 \mathrm{~min}$. Supernatants $(500 \mu \mathrm{l})$ were assayed for radioactivity after adding $4 \mathrm{ml}$ scintillation cocktail. The assays for the oestrogen and progesterone receptors were carried out simultaneously and the tissue from each elephant was analysed separately. The processing of frozen duplicates of the same tissue on different days was used to measure the variability in receptor concentrations within and between assays. The interassay coefficients of variation for the progesterone receptor and oestrogen receptor were $16.9 \%$ and $11.5 \%$, respectively. The intra-assay coefficients of variation for both receptor types was $<10 \%$.

\section{Ligand specificity of the oestrogen and progesterone receptors}

Endometrial and myometrial tissues were chopped finely with a sharp scalpel while frozen in a Petri dish filled with powdered dry ice. A homogeneous mixture was made of the pieces of both types of tissue and this mixture was subsequently homogenized and assayed for oestrogen and progesterone receptors according to the method of Potgieter et al. (1985). Cytosol aliquots $(100 \mu \mathrm{l})$ were incubated in triplicate for $30 \mathrm{~min}$ at $20^{\circ} \mathrm{C}$ with $50 \mu \mathrm{l}$ of either $\left[{ }^{3} \mathrm{H}\right.$ ]oestradiol $\left(8 \times 10^{-9} \mathrm{~mol} \mathrm{l}^{-1}\right)$, or $\left[{ }^{3} \mathrm{H}\right]$ progesterone $\left(8 \times 10^{-9} \mathrm{~mol} \mathrm{l}^{-1}\right)$ in the presence of increasing concentrations $\left(0.3125 \times 10^{-9}\right.$ $\mathrm{mol} \mathrm{l}^{-1}-1 \times 10^{-4} \mathrm{~mol} \mathrm{l^{-1 }}$ ) of each of the following competitors: ORG 2058, norethindrone, promegestone, levonorgestrel, RU 486, medroxyprogesterone, 5a-pregnane3,20-dione, $5 \alpha$-pregnane-3 $\alpha$-ol-20-one, $5 \alpha$-pregnane-3 $\beta$-ol20-one, $\quad 5 \alpha$-pregnane-3 $\beta, 20 \alpha$-diol, $\quad 5 \beta$-pregnane-3,20-dione, $5 \beta$-pregnane-3 $\alpha, 20 \beta$-diol, $\quad 5 \beta$-pregnane-3 $\alpha, 20 \alpha$-diol, $\quad 17 \alpha$ hydroxyprogesterone, II $\alpha$-hydroxyprogesterone, oestradiolI.7 $\beta$, oestrone, oestriol, tamoxifen, pregnenolone, 4-pregnen20 $\alpha$-ol-3-one, hydrocortisone, cortisone, testosterone, dehydrotestosterone and danazol. The reactions were terminated by the addition of dextran-coated charcoal and counted for radioactivity as set out in the previous section.

Each assay included a set of tubes containing a 1000 molar excess of unlabelled DES or progesterone for the oestrogen and progesterone competitive binding assays, respectively; this was used to correct for non-specific binding and to monitor tissue degradation (Wakeling, 1987). If the specific binding did not account for $>60 \%$ of the total binding, the tissue was regarded as degraded and the results were not used. Owing to tissue degradation the final analyses are based on seven samples of endometrial (three from the corpus and four from the fundus regions) and five samples of myometrial tissue (three from the corpus region and two from the fundus regions). Calculation of relative binding affinity was determined 
Table 1. Binding affinities of the oestrogen and progesterone receptors (mean $K_{\mathrm{d}} \times 10^{-9} \mathrm{~mol}^{-1} \pm \mathrm{SEM}$ for the number of individual animals in parentheses) determined by means of 7-point Scatchard plots in nonpregnant, noniactating, female African elephants

\begin{tabular}{lcccc}
\hline & \multicolumn{4}{c}{ Tissue type } \\
\cline { 2 - 5 } & $\begin{array}{c}\text { Endometrial } \\
\text { corpus region } \\
\text { Receptor type }\end{array}$ & $\begin{array}{c}\text { Endometrial } \\
\text { fundus region } \\
(4)\end{array}$ & $\begin{array}{c}\text { Myometrial } \\
\text { corpus region } \\
(3)\end{array}$ & $\begin{array}{c}\text { Myometrial } \\
\text { fundus region } \\
(2)\end{array}$ \\
\hline Oestrogen & $0.140 \pm 0.025$ & $0.185 \pm 0.018$ & $0.223 \pm 0.038$ & $0.190 \pm 0.100$ \\
Progesterone (with $\left[{ }^{3} \mathrm{H}\right]$ promegestone) & $0.250 \pm 0.056$ & $0.235 \pm 0.033$ & $0.233 \pm 0.072$ & $0.135 \pm 0.025$ \\
Progesterone (with $\left[{ }^{3} \mathrm{H}\right.$ ]progesterone) & $0.677 \pm 0.223$ & $1.058 \pm 0.263$ & $1.470 \pm 0.105$ & $0.830 \pm 0.180$ \\
\hline
\end{tabular}

at the $50 \%$ competition level from a displacement curve for each ligand, constructed by plotting the percentage specific binding versus log of the concentration of the competing steroid, followed by the application of Rodbard's equation (1973).

\section{Statistical analyses}

Scatchard and saturation curves with the Rosenthalcorrection for nonspecific binding were drawn by means of the COMBICEPT 2000CA software program (Packard Instrument Company, Downers Grove, IL). Dissociation constant $\left(K_{\mathrm{d}}\right)$ values are given in $10^{-9} \mathrm{~mol} \mathrm{l}^{-1}$ (mean \pm SEM). The Kruskal-Wallis $H$ and Mann-Whitney $U$ test were used to test the differences in binding affinities for the different tissue types. Significance was taken at a $95 \%$ level and mean values are followed by one standard error of the mean. Results from Scatchard plots and the competitive binding assays were subjected to least square regression analyses and only data with correlation coefficients of $\geq 0.9$ were considered reliable for further analyses.

\section{Results}

Estimated mean $K_{d}$ values for the endometrial and myometrial tissue for the oestrogen receptor differed significantly from those values obtained for the progesterone receptor assay with either $\left[{ }^{3} \mathrm{H}\right]$ promegestone or $\left[{ }^{3} \mathrm{H}\right]$ progesterone (Table 1 ). The mean $K_{\mathrm{d}}$ value for the progesterone receptor assay using $\left[{ }^{3} \mathrm{H}\right]$ progesterone as radioligand was significantly higher than that calculated from the binding data when $\left[{ }^{3} \mathrm{H}\right]$ promegestone was used as radioligand. The mean $K_{d}$ value for the oestrogen receptor proved to be significantly lower than that obtained for the progesterone receptor when $\left[{ }^{3} \mathrm{H}\right]$ progesterone was employed as radioligand $(P<0.05)$.

The relative binding affinity and apparent $K_{d}$ values for the various competitors for endometrial progesterone receptors are presented (Table 2). Degradation of the tissue, as discussed previously, precluded estimation of these values for the myometrium, except for the binding of promegestone (relative binding affinity $=199 \%, K_{\mathrm{d}}=0.61 \times 10^{-9} \mathrm{~mol} \mathrm{l}^{-1}$ ), RU 486 (relative binding affinity $<0.1 \%$ ) and oestrone (relative binding affinity $<0.1 \%$ ). These relative binding affinity values were

Table 2. Relative binding affinities and apparent $K_{d}$ values of selected potential competitors for the endometrial progesterone receptor in four nonpregnant, nonlactating female African elephants

\begin{tabular}{lcc}
\hline & $\begin{array}{c}\text { Apparent } K_{d} \\
\left(\times 10^{-9} \mathrm{~mol} \mathrm{l}^{-1}\right)\end{array}$ & $\begin{array}{c}\text { Relative binding } \\
\text { affinity }(\%)\end{array}$
\end{tabular}

ORG 5028

Norethindrone

Promegestone

Progesterone

5 $\alpha$-pregnane-3,20-dione

Levonorgestrel

$5 \alpha$-pregnane-3 $\alpha$-ol-20-one

$5 \alpha$-pregnane-3 $\beta$-ol-20-one

$5 \beta$-pregnane-3,20-dione

0.24
0.30
0.65
0.89
2.10
3.60
4.50
27.00
29.00

0.24
0.30

0.65

0.89

2.10

3.60

27.00

29.00

380
293
138
100
43
24
20
3
3

The relative binding affinity was $<0.1 \%$ for $5 \alpha$-pregnane- $3 \beta, 20 \beta$-diol, $5 \beta$-pregnane-3 $3,20 \beta$-diol, $5 \beta$-pregnane-3 $\alpha, 20 \alpha$-diol, $17 \alpha$-hydroxyprogesterone, 11a-hydroxyprogesterone, medroxyprogesterone, mifepristone (RU 486), oestradiol, oestrone, oestriol, tamoxifen, pregnenolone, 4-pregnen-20a-ol-3one, hydrocortisone, cortisone, testosterone, dehydrotestosterone and danazol. similar to those obtained for the same competitors when tested with endometrial tissue. The progesterone receptor had a high relative binding affinity for both $5 \alpha$-pregnane-3,20dione $(43 \%)$ and $5 \alpha$-pregnane-3a-ol-20-one $(20 \%)$, which are known to be produced in the corpus luteum of the pregnant elephant (Hodges et al., 1994). The two synthetic progestins norethindrone and levonorgestrel, used as oral contraceptives by women, both exhibited a relatively high affinity for the elephant progesterone receptor (norethindrone: relative binding affinity $=293 \%, K_{d}=0.30 \times 10^{-9} \mathrm{~mol} \mathrm{l}^{-1}$ and levonorgestrel: relative binding affinity $=24 \%, K_{d}=$ $3.6 \times 10^{-9} \mathrm{~mol} \mathrm{l}^{-1}$ ). However, RU 486, as well as oestrogens, androgens and corticosteroids, had relative binding affinity values $<0.1 \%$. The competitive binding plots for selected ligands are presented (Fig. 1).

A summary of the relative binding affinity and $K_{d}$ values of the competitors that were tested on the endometrial oestrogen receptor is presented (Table 3). The displacement curves of the most important competitors are given (Fig. 2). These assays were also conducted on the myometrium but, owing to tissue degradation, estinates could be obtained only for DES 


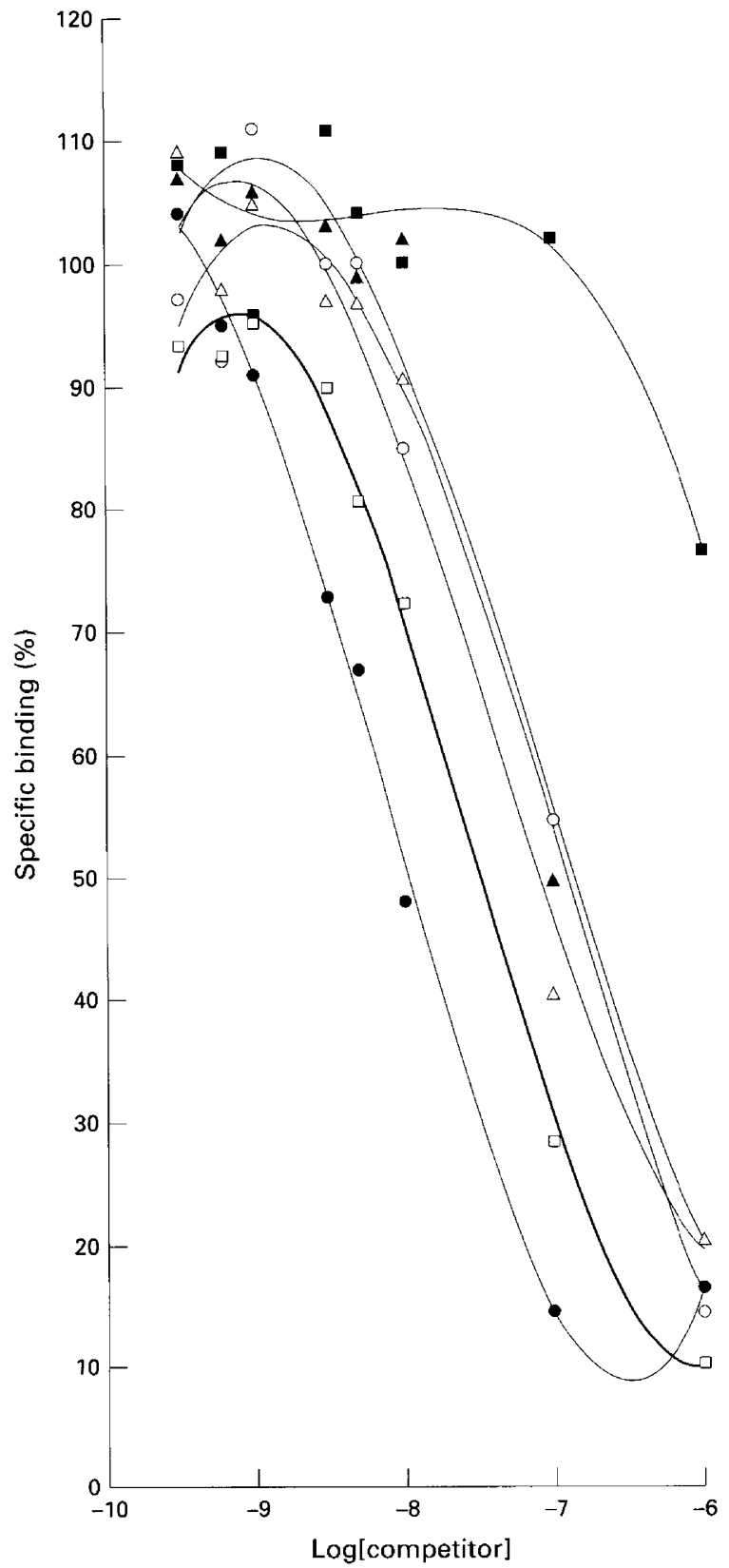

Fig. 1. Competition of various ligands for binding to the endometrial progesterone receptor of African elephants. Norethindrone $(\bullet)$, progesterone $(\Xi)$, 5a-pregnane-3,20-dione $(\Delta)$, levonorgestrel $(\mathbf{\Delta})$, $5 \alpha$-pregnane-3 $\alpha$-ol-20-one (o), RU 486 (匹).

(relative binding affinity $=252 \%, K_{d}=0.083 \times 10^{-9} \mathrm{~mol} \mathrm{l}^{-1}$ ), ethinyl oestradiol (relative binding affinity $=102 \%, K_{\mathrm{d}}=$ $0.20 \times 10^{-9} \mathrm{~mol} \mathrm{l}^{-1}$ ), oestrone (relative binding affinity = $24 \%, K_{d}=0.88 \times 10^{-9} \mathrm{~mol} \mathrm{l}^{-1}$ ) and oestriol (relative binding affinity $=12 \%, K_{d}=1.8 \times 10^{-9} \mathrm{~mol} \mathrm{l}^{-1}$ ). These values were similar to those obtained with the endometrium.

\section{Discussion}

Antiprogestins could prevent conception by creating a uterine environment hostile to implantation (Cooke et al., 1988) and
Table 3. Relative binding affinities and apparent $K_{d}$ values of selected potential competitors for the endometrial oestrogen receptor in four nonpregnant, nonlactating female African elephants

\begin{tabular}{lcc}
\hline Competitor & $\begin{array}{c}\text { Apparent } K_{\mathrm{d}} \\
\left(\times 10^{-9} \mathrm{~mol} \mathrm{l}^{-1}\right)\end{array}$ & $\begin{array}{c}\text { Relative binding } \\
\text { affinity }(\%)\end{array}$ \\
\hline Diethylstilbestrol & 0.14 & 119 \\
Ethinyl oestradiol & 0.15 & 112 \\
Oestradiol & 0.17 & 100 \\
Oestrone & 1.40 & 12 \\
Oestriol & 1.70 & 10
\end{tabular}

The relative binding affinity was $<0.1 \%$ for tamoxifen, progesterone, promegestone, norethindrone, mifepristone (RU 486), 5a-pregnane-3,20-dione, $5 \alpha$-pregnane-3 $\alpha$-ol-20-one, hydrocortisone, cortisone, testosterone and dehydrotestosterone.

this makes the hormone receptor the most specific and most accessible target for intervening in hormone action (Baulieu, 1989). However, differences between species in the uptake, binding and transport of steroids and also in the nature of the progesterone receptor interaction (King and Mainwaring, 1974) caution against the use of synthetic steroids without first examining each compound within the particular species of interest and correlating binding affinity with biological activity (Gray and Leavitt, 1987). No information is available presently on uterine steroid hormone receptors in the African elephant and until the relative binding affinities of the oestrogen and progesterone receptors have been screened for a range of antigestagenic steroids, the potential use of antigestagens such as mifepristone (RU 486) to induce abortion, as suggested by Short (1992), cannot be considered seriously as a means of birth control in elephants. Competitive binding studies, such as those used in the present study, should indicate which antigestagens may be of potential use in the development of techniques to control conception rate in elephant populations. However, a high affinity would still have to be correlated with a biological response in situ.

The only progestagen that competed successfully for the progesterone receptor in the present ligand-binding studies was norethindrone, which bound to the receptor nearly three times as strongly as progesterone. Norethindrone and norethindrone acetate are used widely to prevent pregnancy in women (Taitel et al., 1995). Low doses of norethindrone and of levonorgestrel (relative binding affinity $=24 \%$ in the present study) are considered to have an antifertility effect, while high doses can have an anti-ovulatory effect (Lobo and Stanczyk, 1994). Alternatively, RU 486, which is known to act strongly as an antiprogestin in humans (Gravanis et al., 1985), rabbits and rats (Philibert, 1984), showed a very low affinity for both the progesterone and oestrogen receptors of the uterus of the African elephant. A low relative binding affinity for RU 486 has also been reported in hamsters (Gray and Leavitt, 1987), chickens (Groyer et al., 1985) and tammar wallabies (Fletcher and Blandon, 1988). Gray and Leavitt (1987) found that in hamsters the low binding affinity of the progesterone receptor for RU 486 did not prevent decidualization and normal implantation in the uterus. Should this be the case for 


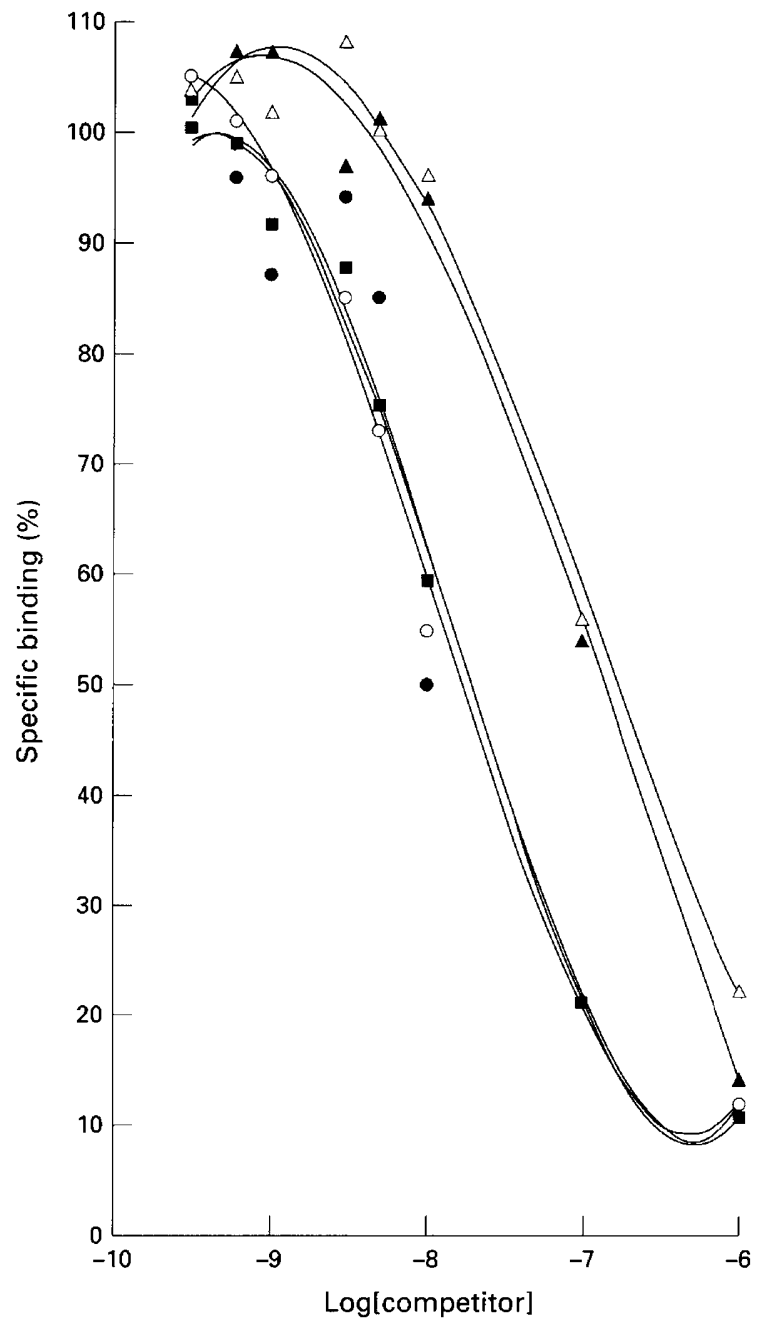

Fig. 2. Competition of various ligands for binding to the endometrial oestrogen receptor of African elephants. Ethinyl oestradiol (•), diethylstilbestrol $(0)$, oestrone $(\Delta)$, oestriol $(\Delta)$, oestradiol $(\mathbf{\bullet})$.

elephants, RU 486 could no longer be considered to be of potential use to control elephant reproductive output (Short, 1992; Poole, 1993). Although comparative strong binding to the receptor does predict a possible potency as a contraceptive agent, as suggested for norethindrone and levonorgestrel in this present study, a discrepancy in the observed potency may still arise once an agent is applied.

Neither of the two $5 \alpha$-reduced metabolites of progesterone (5 $\alpha$-pregnane-3,20-dione and $5 \alpha$-pregnane-3 $\alpha$-ol-20-one), known to be produced in the corpus luteum of elephants (Hodges et al., 1994), had a stronger binding affinity for the progesterone receptor than for progesterone. However, affinity is not the only criterion that determines biological efficiency. Despite a low affinity, a low metabolic clearance rate could ensure sustained concentrations in the blood and thereby increase efficiency markedly (Sutherland and Jordan, 1981). Biological potency therefore depends on a combination of receptor affinity and persistence in target tissues (Katzenellenbogen, 1980). The relatively high binding affinity of the progesterone receptor in the elephant for $5 \alpha$-dihydroprogesterone $(43 \%)$ which occurs at a 10-20 fold higher concentration than progesterone in the plasma of pregnant animals (Heistermann et al., 1994), suggests that this metabolite may have some biological activity in this species. The metabolic clearance rate of the $5 \alpha$-reduced metabolites of progesterone, and the binding affinities of carrier proteins for these substances in the plasma, have yet to be determined for the African elephant. Until these studies are undertaken it remains inappropriate to speculate further on the biological significance of $5 \alpha$-dihydroprogesterone in this species. However, it is worth noting that progesterone metabolites can act as intracellular mediators of progesterone action in the endometrium (Armstrong and King, 1971).

In the present study, $5 \beta$-isomers of progesterone displayed a very low binding affinity for the progesterone receptor when compared to $5 \alpha$-reduced metabolites. This finding is in agreement with King and Mainwaring (1974), who found that $5 \alpha$-reduced compounds usually retain some of the biological properties of the parent compound, whereas $5 \beta$-isomers lose or change the properties completely.

In the African elephant, both the oestrogen and progesterone receptors proved to be highly specific. Oestradiol had nearly the same affinity for the oestrogen receptor as ethinyl oestradiol and DES, while tamoxifen had a very low affinity for the receptor. This low affinity may have been caused by the hydrophobic nature of tamoxifen resulting in the adsorption to the glass or plastic apparatus, thereby leading to significant errors at low concentrations (Wakeling, 1987). It is more likely, however, that the 4-hydroxytamoxifen metabolite of tamoxifen would have had a stronger affinity for the oestrogen receptor than that of tamoxifen since Rochefort et al. (1979) found that this metabolite is ten times more potent than its parent compound.

The fact that the progesterone receptor assays using $\left[{ }^{3} \mathrm{H}\right]$ promegestone had a significantly lower $K_{\mathrm{d}}$ value than the assays using $\left[{ }^{3} \mathrm{H}\right]$ progesterone, indicates that this receptor has a higher affinity for promegestone than for progesterone. This higher affinity can be explained by the knowledge that promegestone has a high progestin selectivity (Ojasoo, 1995), a nanomolar $K_{d}$ value for the progesterone receptor and an inability to recognise corticosteroid-binding globulin (Milgrom et al., 1973). The $K_{\mathrm{d}}$ values for the endometrial and myometrial oestrogen and progesterone receptors were similar, suggesting that the receptors of these tissues may have similar molecular characteristics. This possibility is further supported by the observed similarity in relative binding affinity values of competitors obtained for receptors in both the endometrium and the myometrium. This finding is also in agreement with the observation of Grossman and Leavitt (1974) who showed that progesterone receptors in the endometrium of hamsters have the same physiochemical properties as the receptors in the myometrium. However, the myometrial tissue did prove to be more labile than the endometrial tissue, probably as a result of a time-delay in preservation during field collection.

On the basis of the present study we conclude that, in the African elephant, the $5 \alpha$-reduced progesterone metabolites are of some biological importance, since these substances bound to the progesterone receptor with a relatively high affinity. Furthermore, RU 486, with its low affinity for the progesterone receptor, appears to be unsuitable as a potential antifertility agent in the African elephant. In this regard, the high relative 
binding affinity of norethindrone for the progesterone receptor deserves further investigation. Both oestrogen and progesterone receptors proved to be highly specific, which necessitates the screening of all anti-gestagenic substances before they can be applied to reduce the reproductive output in elephants.

This study was financially supported by the Foundation of Research Development and sanctioned by the National Parks Board. I. Whyte and C. Wood of the latter organization provided valuable assistance with the collection of study material. The authors thank SA-Druggists and Roussel Uclaf for their donations of steroids. B. Potgieter, J. Spies and D. Moss from the University of Pretoria provided technical assistance. M. D. Greyling was the recipient of scholarships from the Foundation of Research Development and the Bob Blundell Memorial Trust.

\section{References}

Armstrong DT and King ER (1971) Uterine progesterone metabolism and progestational response: effects of oestrogens and prolactin Endocrinology $\mathbf{8 9}$ 191-197

Baulieu EE (1989) Contragestion and other clinical applications of RU 38486, an antiprogesterone at the receptor Science $2451351-1357$

Bradford MM (1976) A rapid and sensitive method for the quantitation of microgram quantities of protein, utilizing the principle of protein-dye binding Analytical Biochemistry 72 248-254

Brannian JD, Griffen F, Papkoff H and Terranova PF (1988) Short and long phases of progesterone secretion during the oestrous cycle of the African elephant, Loxodonta africana. Journal of Reproduction and Fertility 84 357-365

Cooke BA, King RJB and Van der Molen HJ (1988) Hormones and their actions. Part 1. Elsevier, Amsterdam

De Villiers DJ, Skinner JD and Hall-Martin AJ (1989) Circulating progesterone concentrations and ovarian functional anatomy in the African elephant, Loxodonta africana. Journal of Reproduction and Fertility 86 195-201

Fletcher TP and Blandon DR (1988) The antigestagens RU 486 and ZK 299 are not bound by the uterine progesterone receptor of the tammar wallaby, Macropus exigenii. Twentieth Annual Conference of the Australian Society for Reproductive Biology Abstract 50

Gravanis A, Schaison G, George M, de Brux J, Satyaswaroop PG, Baulieu EE and Robel $P$ (1985) Endometrial and pituitary responses to the steroidal antiprogestin RU 486 in postmenopausal women Journal of Clinical Endocrinology and Metabolism 60 156-163

Gray GO and Leavitt WW (1987) RU 486 is not an antiprogestin in the hamster Journal of Steroid Biochemistry 28 493-497

Grossman CJ and Leavitt WW (1974) Progesterone receptors in endometrium and myometrium of hamster uterus Federation Proceedings 33268

Groyer A, Le Bouc Y, Radanyi C, Renior J, Robel P and Baulieu EE (1985) Chick oviduct glucocorticosteriod receptor-specific binding of the synthetic steroid RU 486 and immunological studies with antibodies to chick oviduct progesterone receptor European Journal of Biochemistry 149 445-451

Hall-Martin AJ (1992) The question of culling. In Elephants - Majestic Creatures of the Wild pp 194-201 Ed. J Shoshani. Weldon Owen Inc., San Francisco

Hanks J and Short RV (1972) The formation and function of the corpus luteum in the African elephant, Loxodonta africana. Journal of Reproduction and Fertility $2979-89$
Heistermann M, Beard A, Van Aarde RJ and Hodges JK (1994) Progesterone and $5 \alpha$-dihydroprogesterone concentrations in plasma and individual corpora lutea of non-pregnant and pregnant African elephants. Joumal of Reproduction and Fertility Abstract Series 13 Abstract 28

Hodges JK, Henderson C and McNeilly AS (1983) Circulating oestrogen concentrations during pregnancy in the African elephant, Loxodonta africana. Journal of Reproduction and Fertility 67 121-127

Hodges JK, Van Aarde RJ, Heistermann M and Hoppen HO (1994) Progestin content and biosynthetic potential of the corpus luteum of the African elephant, Loxodonta africana. Journal of Reproduction and Fertility 102 163-168

Katzenellenbogen BS (1980) Dynamics of steroid hormone action Annual Review of Physiology 42 17-35

King RJB and Mainwaring WIP (1974) Steroid-cell interactions. Butterworth and Co. Ltd, London

Leake RE and Habib F (1987) Steroid hormone receptors: assay and characterization. In Steroid hormones - A Practical Approach pp 67-97 Eds B Green and RE Leake. IRL Press limited, Oxford

Lobo RA and Stanczyk FZ (1994) New knowledge in the physiology of hormonal contraceptives American Journal of Obstetrics and Gynaecology 170 1499-1507

McNeilly AS, Martin RD, Hodges JK and Smuts GL (1983) Blood concentrations of gonadotrophins, prolactin and gonadal steroids in males and in nonpregnant and pregnant female African elephants (Loxodonta africana) Journal of Reproduction and Fertility 67 113-120

Milgrom E, Luu Thi M and Baulieu EE (1973) Control mechanism of steroid hormone receptors in the reproductive tract Acta Endocrinologica Supplementum 180 380-403

Ojasoo T (1995) Multivariate preclinical evaluation of progestins Menopause 2 $97-107$

Philibert D (1984) An original multifaceted antihormone in vivo. In Adrenal Steroid Antagonism pp 77--101 Ed. MK Agarwal. Walter de Gruyter, Berlin

Plotka ED, Seal US, Zarembka FR, Simmons LG, Teare A, Phillips LG, Hindshaw KC and Wildt DG (1988) Ovarian function in the elephant: luteinizing hormone and progesterone cycles in African and Asian elephants Biology of Reproduction 38 309-314

Poole JH (1993) Kenya's initiatives in elephant fertility regulation and population control techniques Pachyderm 16 62-65

Potgieter HC, Spies JH, Klein T, Thierry M and Van der Watt JJ (1985) Oestrogen and progesterone receptors in the uterus of the vervet monkey journal of Receptor Research 5 193-218

Rochefort H, Garcia M and Borgna JL (1979) Absence of correlation between antiestrogenic activity and binding affinity for the oestrogen receptor Biochemical and Biophysical Research Communications $88351-357$

Rodbard D (1973) Mathematics of hormone-receptor interaction Advances in Experimental Medical Biology 36 289-326

Short RV (1992) Elephants and birth control New Scientist 135 21-23

Smith NS and Buss IO (1975) Formation, function and persistence of the corpora lutea of the African elephant, Loxodonta africana Journal of Mammalogy 56 30-43

Sutherland RL and Jordan VC (1981) Non-steroidal Antioestrogens. Molecular Pharmacology and Antitumour Activity. Academic Press, Australia

Taitel HF and Kafrissen ME (1995) Norethindrone - a review of therapeutic applications International Journal of Fertility $\mathbf{4 0} 207-223$

Wakeling AE (1987) Anti-hormones and other steroid analogues. In Steroid Hormones - A Practical Approach pp 219--236 Eds B Greene and RE Leake. IRL. Press limited, Oxford 